\title{
Epinephrine-induced Insulin Resistance in Man
}

\author{
David C. Deibert and Ralph A. DeFronzo, Department of Internal Medicine, \\ Yale University School of Medicine, New Haven, Connecticut 06510
}

A в S T RACT Endogenous release of epinephrine after stress as well as exogenous epinephrine infusion are known to result in impaired glucose tolerance. Previous studies of man and animals have demonstrated that this effect of epinephrine results from inhibition of insulin secretion and augmentation of hepatic glucose production. However, the effect of epinephrine on tissue sensitivity to insulin, and the relative contributions of peripheral vs. hepatic resistance to impaired insulin action, have not been defined. Nine young normal-weight subjects were studied with the insulin clamp technique. Plasma insulin was raised by $\sim 100$ $\mu \mathrm{U} / \mathrm{ml}$ while plasma glucose concentration was maintained at basal levels by a variable glucose infusion. Under these conditions of euglycemia, the amount of glucose metabolized equals the glucose infusion rate and is a measure of tissue sensitivity to insulin. Subjects received four studies: $(a)$ insulin $\left(42.6 \mathrm{mU} / \mathrm{m}^{2} \cdot \mathrm{min}\right),(b)$ insulin plus epinephrine $(0.05 \mu \mathrm{g} / \mathrm{kg} \cdot \mathrm{min}),(c)$ insulin plus epinephrine plus propranolol $(1.43 \mu \mathrm{g} / \mathrm{kg} \cdot \mathrm{min})$, and $(d)$ insulin plus propranolol. During insulin administration alone, glucose metabolism averaged $5.49 \pm 0.58 \mathrm{mg} / \mathrm{kg} \cdot \mathrm{min}$. When epinephrine was infused with insulin, glucose metabolism fell by $41 \%$ to 3.26 $\mathrm{mg} / \mathrm{kg} \cdot \mathrm{min}(P<0.001)$. After insulin alone, hepatic glucose production declined by $92 \%$ to $0.16 \pm 0.08$ $\mathrm{mg} / \mathrm{kg} \cdot \mathrm{min}$. Addition of epinephrine was associated with a delayed and incomplete suppression of glucose production $(P<0.01)$ despite plasma insulin levels $>100 \mu \mathrm{U} / \mathrm{ml}$. When propranolol was administered with epinephrine, total glucose metabolism was restored to control values and hepatic glucose production suppressed normally. Propranolol alone had no effect on insulin-mediated glucose metabolism. These results indicate that epinephrine, acting primarily through a $\beta$-adrenergic receptor, markedly impairs tissue sensitivity to an increase in plasma insulin levels, and that this effect results from both peripheral and hepatic resistance to the action of insulin.

Received for publication 21 September 1979 and in revised form 2.9 October 1979.

\section{INTRODUCTION}

Epinephrine infusion has long been known to induce hyperglycemia in man and experimental animals. Several studies have documented that epinephrine inhibits insulin secretion (1-5) and augments hepatic glucose output by stimulating both gluconeogenesis (6-10) and glycogenolysis (11). Although in vitro studies employing skeletal muscle have shown that epinephrine also impairs tissue uptake of glucose (1214) and in vivo studies have suggested an epinephrineinduced decrement in the metabolic clearance rate of glucose $(1,2)$, an in vivo effect of epinephrine on peripheral glucose metabolism independent of changes in plasma insulin levels has not been conclusively documented. Because epinephrine is known to inhibit insulin secretion (1-5), inhibition of glucose uptake may be secondary to the decline in plasma insulin concentration.

Attempts to categorize the metabolic effects of epinephrine as either alpha $(\alpha)$ or beta $(\beta)$ receptormediated have yielded contradictory results. It has been reported that neither $\alpha$-nor $\beta$-blockade alone is sufficient to prevent the hyperglycemic effect of epinephrine infusion in normal man, but that combined propranolol and phentolamine pretreatment abolishes the hyperglycemic effect of epinephrine infusion (15). In diabetic subjects (16) propranolol pretreatment alone partially prevented epinephrine-induced hyperglycemia, but phentolamine had no effect on the rise in plasma glucose concentration. In vitro studies have shown that propranolol is capable of preventing the epinephrine-induced inhibition of insulin-mediated glucose uptake by rat diaphragmi $(12,14)$.

In the present study we have employed the euglycemic insulin clamp technique in combination with tritiated glucose to quantitate the effect of epinephrine on tissue sensitivity to insulin, and to define the relative contributions of peripheral vs. hepatic resistance to the action of insulin. We have also demonstrated that the effects of epinephrine on both hepatic and peripheral glucose metabolism are mediated primarily via the $\beta$-adrenergic receptor. 


\section{METHODS}

Subjects. The study group consisted of nine healthy volunteers (five females and four males) ranging in age from 23 to $30 \mathrm{yr}($ mean \pm SEM $=26 \pm 1 \mathrm{yr})$, and in ideal body weight (based on Metropolitan Life Insurance tables, 1959) from 90 to $112 \%$ of the normal (mean $=99 \pm 2 \%$ ). All subjects were consuming a weight-maintaining diet containing at least $200 \mathrm{~g}$ of carbohydrate/d for at least $3 \mathrm{~d}$ before study. No subjects consumed any medications during the 4 wk before study. Each subject served as his own control. All studies were carried out in the postabsorptive state at $8 \mathrm{a} . \mathrm{m}$. after a 12-h overnight fast. The purpose and potential risks of the study were explained to each subject; written voluntary consent was obtained before participation.

Insulin clamp studies. Tissue sensitivity to insulin was determined by the insulin clamp technique as described (17). After a 120 -min control period to allow for equilibration of $\left[3-{ }^{3} \mathrm{H}\right]$ glucose (18), a priming plus continuous infusion of crystalline procine insulin (Eli Lilly \& Co., Indianapolis, Ind.) was administered to obtain constant physiological hyperinsulinemia. The priming dose was administered in a logarithmically falling manner over $10 \mathrm{~min}$, at which time the continuous infusion was initiated. The continuous insulin infusion was given at a rate of $42.6 \mathrm{mU} / \mathrm{m}^{2}$ surface area per min and was maintained for $110 \mathrm{~min}$. The plasma glucose was maintained at basal preinfusion levels by the determination of plasma glucose concentration every $5 \mathrm{~min}$ and the periodic adjustment of a variable infusion of $20 \%$ glucose solution (17). Under these steady-state conditions of constant euglycemia, all of the glucose infused was taken up by the cells.

Each subject subsequently underwent a repeat insulin clamp study with the infusion of epinephrine. The procedure was identical to that outlined above except that a constant infusion of epinephrine at a rate of $0.05 \mu \mathrm{g} / \mathrm{kg}$ body wt per min was initiated simultaneously with the infusion of insulin. The epinephrine infusate (Parke-Davis Co., Detroit, Mich.) was prepared with normal saline and the addition of ascorbic acid, $1.0 \mathrm{mg} / \mathrm{ml}$ of infusate, to prevent autooxidation.

Each subject underwent a third insulin clamp study during which propranolol was infused with epinephrine. The propranolol (Inderal, Ayerst Laboratories, New York.) was administered as a priming dose of $0.001 \mathrm{mg} / \mathrm{kg}$ body weight per minute during the $5 \mathrm{~min}$ preceding the initiation of insulin infusion. The propranolol infusion was then continued at a rate of $0.001 \mathrm{mg} / \mathrm{kg} \cdot \mathrm{min}$ in concert with the infusion of epinephrine at a rate of $0.05 \mu \mathrm{g} / \mathrm{kg}$ body wt per min for the ensuing $120 \mathrm{~min}$ of the insulin clamp procedure.

Finally, each subject underwent an insulin clamp during which propranolol alone was infused. The propranolol was administered as a prime-continuous infusion as described above.

Calculations. During the insulin clamp studies, the glucose infusion rate was determined by calculating the mean value observed during selected time intervals. Total glucose metabolism during a given time period was calculated by adding the mean rate of endogenous glucose production during that time period to the mean glucose infusion rate during the same time period. To calculate the steady-state plasma glucose and insulin concentrations during the insulin infusion, the mean values from 20 to 120 min were employed. The metabolic clearance rate of insulin was calculated by dividing the continuous insulin infusion rate $\left(42.6 \mathrm{mU} / \mathrm{m}^{2}\right.$. $\mathrm{min}$ ) by the mean increment above basal in plasma insulin concentration during the 20-120 min time period.

After the initiation of the insulin-glucose infusion during the insulin clamp procedures, glucose production in the basal state was determined as described (17). The rate of endogenous glucose production was calculated by subtracting the glucose infusion rate from the rate of glucose appearance as determined with tritiated glucose.
All data are presented as the mean \pm SEM. Statistical comparisons were calculated by Student's $t$ test for paired analysis.

Analytical procedures. Plasma glucose concentration was measured by the glucose oxidase method with a Beckman glucose analyzer (Beckman Instruments, Inc., Fullerton, Calif.). Methods for the determination of plasma immunoreactive insulin, glucagon (with Unger antibody $30 \mathrm{~K}$ ), amino acids (19), and tritiated plasma glucose specific activity (18) have been described previously. Plasma epinephrine levels were determined by Dr. Rosa Hendler employing a radioenzymatic assay (20).

\section{RESULTS}

Plasma glucose, insulin, glucagon, and epinephrine concentration (Table I). Mean steady-state plasma insulin concentrations were maintained at $\sim 132-135$ $\mu \mathrm{U} / \mathrm{ml}$ during all four insulin clamp studies. During all studies the plasma glucose was held close to the basal level. The stability of the plasma insulin and glucose levels is indicated by the small coefficients of variation. The metabolic clearance rate of insulin averaged $361 \pm 12 \mathrm{ml} / \mathrm{m}^{2} \cdot \min$ during the control study and was unchanged by epinephrine $\left(361 \pm 16 \mathrm{ml} / \mathrm{m}^{2}\right.$. $\mathrm{min})$, epinephrine and propranolol $\left(364 \pm 12 \mathrm{ml} / \mathrm{m}^{2}\right.$. $\mathrm{min})$, or propranolol alone $\left(370 \pm 14 \mathrm{ml} / \mathrm{m}^{2} \cdot \mathrm{min}\right)$. Plasma glucagon concentration fell slightly during the control insulin clamp study $(P<0.05)$ and was unchanged when epinephrine was infused with insulin. During both clamp studies in which propranolol was infused, the decline in plasma glucagon was similar to the control insulin clamp study $(P<0.05)$. Fasting plasma epinephrine levels were similar during all four studies and were unchanged during the control insulin clamp study or by the infusion of propranolol alone. When epinephrine alone was infused, the mean plasma epinephrine level during the 60-120 min time period was $736 \pm 23 \mathrm{pg} / \mathrm{ml}$. When propranolol was infused with epinephrine, the mean plasma epinephrine concentration was significantly higher than with epinephrine alone, $1,441 \pm 96 \mathrm{pg} / \mathrm{ml}(P<0.001)$.

Glucose metabolism (Tables II and III). During the basal state the rate of glucose metabolism by the entire body must equal the endogenous glucose production rate; it was similar during control, epinephrine, epinephrine-propranolol, and propranolol insulin clamp studies (Table II). During the control study, a small increase in total body glucose metabolism (Table III) was observed during the first $20 \mathrm{~min}$ after insulin administration. During the 20-60-min time period, glucose metabolism rose progressively and then tended to level off during the last $60 \mathrm{~min}$. The rate of glucose metabolism during the entire $120-\mathrm{min}$ study period averaged $5.49 \pm 0.58 \mathrm{mg} / \mathrm{kg} \cdot \mathrm{min}$.

When epinephrine was infused with insulin, tissue sensitivity to insulin was markedly impaired. Similar to the control study, during the first $20 \mathrm{~min}$ a small increase in glucose metabolism occurred. For the remaining $100 \mathrm{~min}$, however, no further increase in glucose metabolism was observed; the rate of glucose 
TABLE I

Plasma Insulin, Glucose, Glucagon and Epinephrine Concentrations during the Control, Epinephrine Infusion, Epinephrine-Propranolol, and Propranolol Insulin Clamp Studies

\begin{tabular}{|c|c|c|c|c|c|c|c|c|c|c|}
\hline & \multicolumn{3}{|c|}{ Insulin } & \multicolumn{3}{|c|}{ Glucose } & \multicolumn{2}{|c|}{ Glucagon } & & \\
\hline & \multirow{2}{*}{$\begin{array}{l}\text { Basal } \\
\text { plasma } \\
\text { insulin } \\
\text { concen- } \\
\text { tration }\end{array}$} & \multirow{2}{*}{$\begin{array}{l}\text { Steady- } \\
\text { state } \\
\text { plasma } \\
\text { insulin } \\
\text { concen- } \\
\text { tration }\end{array}$} & \multirow[b]{2}{*}{$\begin{array}{c}\text { Coefficient } \\
\text { of } \\
\text { variation }\end{array}$} & \multirow{2}{*}{$\begin{array}{l}\text { Basal } \\
\text { plasma } \\
\text { glucose } \\
\text { concen- } \\
\text { tration }\end{array}$} & \multirow{2}{*}{$\begin{array}{l}\text { Steady- } \\
\text { state } \\
\text { plasma } \\
\text { glucose } \\
\text { concen- } \\
\text { tration }\end{array}$} & \multirow[b]{2}{*}{$\begin{array}{c}\text { Coefficient } \\
\text { of } \\
\text { variation }\end{array}$} & \multirow{2}{*}{$\begin{array}{c}\text { Basal } \\
\text { plasma } \\
\text { glucagon } \\
\text { concen- } \\
\text { tration }\end{array}$} & \multirow[b]{2}{*}{$\begin{array}{c}\text { Plasma } \\
\text { glucagon } \\
\text { post insulin }\end{array}$} & \multicolumn{2}{|c|}{ Epinephrine } \\
\hline & & & & & & & & & $\begin{array}{l}\text { Basal plasma } \\
\text { epinephrine }\end{array}$ & $\begin{array}{l}\text { Plasma } \\
\text { epinephrine } \\
\text { post insulin }\end{array}$ \\
\hline & $\mu U / m l$ & $\mu U / m l$ & $\%$ & $m g / d l$ & $m g / d l$ & $\%$ & $p g / m l$ & $p g / m l$ & $p g / m l$ & $p g / m l$ \\
\hline Insulin & $15 \pm 1$ & $1.32 \pm 3$ & 2 & $85 \pm 1$ & $85 \pm 2$ & 4 & $66 \pm 5$ & $50 \pm 3 *$ & $21 \pm 3$ & $24 \pm 5$ \\
\hline Insulin + epinephrine & $17 \pm 1$ & $135 \pm 3$ & 2 & $86 \pm 3$ & $88 \pm 3$ & 5 & $69 \pm 6$ & $74 \pm 3$ & $25 \pm 5$ & $736 \pm 23$ \\
\hline Insulin + epinephrine & & & & & & & & & & \\
\hline + propranolol & $16 \pm 1$ & $133 \pm 3$ & 3 & $88 \pm 2$ & $89 \pm 2$ & 5 & $70 \pm 8$ & $52 \pm 4^{*}$ & $36 \pm 4$ & $1,441 \pm 96$ \\
\hline Insulin + propranolol & $14 \pm 1$ & $133 \pm 6$ & 4 & $83 \pm 4$ & $87 \pm 3$ & 3 & $70 \pm 5$ & $55 \pm 5^{*}$ & $28 \pm 5$ & $33 \pm 6$ \\
\hline
\end{tabular}

All values represent the mean \pm SEM.

* $P<0.05$ compared with the basal state.

$\ddagger \mathrm{P}<0.001$ compared with epinephrine alone.

metabolism during the 120 -min study period $(3.26$ $\pm 0.24 \mathrm{mg} / \mathrm{kg} \cdot \mathrm{min}$ ) was significantly less than the control's $(P<0.001)$. When propranolol was infused with epinephrine, glucose metabolism was similar to the control insulin clamp study during all time intervals; and rate of glucose metabolism during the $120 \mathrm{~min}$ $(5.73 \pm 0.67 \mathrm{mg} / \mathrm{kg} \cdot \mathrm{min})$ was not significantly different from the control study. Propranolol alone had no significant effect on glucose metabolism; the rate of glucose metabolism during the 120 -min study period $(5.28$ $\pm 0.42 \mathrm{mg} / \mathrm{kg} \cdot \mathrm{min}$ ) was similar to the control insulin clamp study.

Endogenous glucose production (Table II). During the control insulin clamp study, hepatic glucose production declined promptly to $0.49 \pm 0.16 \mathrm{mg} / \mathrm{kg}$. min during the first $20 \mathrm{~min}$ and remained suppressed throughout the period of hyperinsulinemia. In contrast, epinephrine markedly blunted the hepatic response to insulin. During the first $20 \mathrm{~min}$ after the initiation

TABLE II

Endogenous Glucose Production during the Control, Epinephrine, Epinephrine-Propranolol and Propranolol Insulin Clamp Studies

\begin{tabular}{ccccc}
\hline & \multicolumn{5}{c}{ Endogenous glucose production } \\
\cline { 2 - 5 } Time & Insulin & $\begin{array}{c}\text { Insulin } \\
+ \text { epinephrine }\end{array}$ & $\begin{array}{c}\text { Insulin } \\
+ \text { epinephrine } \\
+ \text { propranolol }\end{array}$ & $\begin{array}{c}\text { Insulin } \\
+ \text { propranolol }\end{array}$ \\
\hline min & \multicolumn{5}{c}{$\mathrm{mg} / \mathrm{kg} \cdot \min$} \\
Basal & $2.05 \pm 0.10$ & $2.17 \pm 0.10$ & $2.06 \pm 0.07$ & $1.92 \pm 0.12$ \\
$0-20$ & $0.49 \pm 0.16$ & $2.58 \pm 0.32^{*}$ & $0.61 \pm 0.16$ & $0.37 \pm 0.16$ \\
$20-60$ & $0.25 \pm 0.11$ & $1.07 \pm 0.28^{*}$ & $0.24 \pm 0.13$ & $0.25 \pm 0.15$ \\
$60-120$ & $0.16 \pm 0.08$ & $0.73 \pm 0.18^{*}$ & $0.19 \pm 0.08$ & $0.15 \pm 0.12$
\end{tabular}

All values represent the mean \pm SEM.

* $P<0.005$ compared with the same time interval for controls, epinephrine-propranolol, and propranolol. of the insulin infusion, a small rise in hepatic glucose production occurred ( $P<0.001$ vs. control). Thereafter, endogenous glucose production fell progressively, but the percent suppression during the 20-60-min $(51$ vs. $88 \%)$ and $60-120-\min (66$ vs. $92 \%)$ time periods was significantly less than the control's $(P<0.005)$. The stimulatory effect of epinephrine on hepatic glucose production was completely blocked by the simultaneous infusion of propranolol. The infusion of propranolol alone had no effect on the ability of insulin to suppress endogenous glucose production.

Plasma amino acid concentrations. During the control insulin clamp study, a significant decline in the circulating plasma levels of all amino acids, except alanine, was observed. When epinephrine was infused with insulin, the decline in all plasma amino acids except alanine was potentiated. This was true whether the decrease was expressed on an absolute basis or as the percent decrease from basal $(P<0.02)$. When propranolol was infused with epi-

\section{TABLE III}

Glucose Metabolism during the Control, Epinephrine, Epinephrine-Propranolol and Propranolol Insulin Clamp Studies

\begin{tabular}{ccccc}
\hline & \multicolumn{5}{c}{ Total glucose metabolism } \\
\cline { 2 - 5 } Time & Insulin & $\begin{array}{c}\text { Insulin } \\
+ \text { epinephrine }\end{array}$ & $\begin{array}{c}\text { Insulin } \\
+ \text { epinephrine } \\
+ \text { propranolol }\end{array}$ & $\begin{array}{c}\text { Insulin } \\
+ \text { propranolol }\end{array}$ \\
\hline min & \multicolumn{4}{c}{ mg/kg $\cdot \min$} \\
$0-20$ & $3.35 \pm 0.27$ & $3.12 \pm 0.24$ & $3.37 \pm 0.46$ & $3.79 \pm 0.27$ \\
$20-60$ & $5.17 \pm 0.56$ & $2.96 \pm 0.34^{*}$ & $5.19 \pm 0.59$ & $4.71 \pm 0.53$ \\
$60-120$ & $6.77 \pm 0.76$ & $3.34 \pm 0.24^{*}$ & $6.78 \pm 0.78$ & $6.00 \pm 0.91$
\end{tabular}

All values represent the mean \pm SE.M

$* P<0.005$ compared with the same time interval for controls, epinephrine-propranolol, and propranolol. 
nephrine, the potentiating effect was reversed and the decline in plasma amino acid levels was similar to the control insulin clamp study. Propranolol alone had no effect on the plasma amino acid response to hyperinsulinemia.

\section{DISCUSSION}

Impaired glucose tolerance after epinephrine infusion could result from decreased insulin secretion or diminished tissue responsiveness to insulin. Although epinephrine has been shown to inhibit insulin secretion in vivo (1-5), a similar inhibitory effect on tissue sensitivity to insulin has not been documented in man. In the present study we have employed the euglycemic insulin clamp technique in combination with tritiated glucose to quantitate the effect of epinephrine on tissue sensitivity to insulin, and to define the relative contributions of peripheral tissues vs. the liver to the observed insulin resistance. This technique, by maintaining the plasma insulin concentration constant, avoids the epinephrine-induced fall in plasma insulin that could secondarily result in a decline in glucose metabolism. Also, by clamping the plasma glucose concentration at the basal level, it avoids epinephrineinduced hyperglycemia, which of itself could enhance glucose metabolism and obscure an inhibitory effect of epinephrine.

The present results indicate that the infusion of epinephrine, to achieve plasma levels observed in stress (21) and diabetic ketoacidosis (22), results in a marked decrease in tissue sensitivity to physiologic hyperinsulinemia. The effect of smaller doses of epinephrine, as might be expected in mild to moderate stress, was not examined in the present study. However, studies by Soman et al. (23) suggest that a similar antagonistic effect would be expected. During the 2 -hr study period the total amount of glucose metabolized was significantly reduced in each of the nine subjects by a mean value of $41 \%$. In a previous study we showed that under the present conditions of euglycemic hyperinsulinemia little or no glucose is taken up by the liver (24). Because with epinephrine the rate of glucose metabolism during the last hour of study was decreased by $3.43 \mathrm{mg} / \mathrm{kg} \cdot \min (6.77$ to 3.34$)$, a major part of the insulin resistance must reside in peripheral tissues, probably muscle. This observation is consistent with in vitro studies demonstrating an inhibitory action of epinephrine on insulin-mediated glucose metabolism (12-14).

Epinephrine also inhibited the ability of hyperinsulinemia to supress hepatic glucose production normally. During the control study, hepatic glucose production declined to $24 \%$ of basal within the first 20 min after insulin administration and remained suppressed throughout the remainder of the study. In contrast, epinephrine blocked the inhibitory effect of insulin on hepatic glucose production, and during the first $20 \mathrm{~min}$ glucose output actually increased over basal levels. After $20 \mathrm{~min}$, hepatic glucose production began to decline but still remained fourfold higher than during the control insulin clamp study at the end of the 2-h study period. Several previous reports have shown a stimulatory effect of epinephrine on hepatic glucose production, but the plasma insulin levels in these studies either remained at basal levels (3) or increased only minimally and transiently $(1,2)$ as a result of the simultaneous inhibitory effect of epinephrine on insulin secretion. The present study documents that even in the face of persistent hyperinsulinemia (plasma insulin concentration of $>100$ $\mu \mathrm{U} / \mathrm{ml}$ ), stress-associated levels of epinephrine are capable of augmenting hepatic glucose production. Because plasma glucagon fell by $16 \mathrm{pg} / \mathrm{ml}$ during the control insulin clamp study, but failed to suppress when epinephrine was infused with insulin, it is possible that part of the lessened effect of insulin on endogenous glucose production is attributable to the higher plasma glucagon levels.

Propranolol, a specific $\beta$-blocker, completely prevented the effects of epinephrine on the liver. The endogenous glucose production rate during the combined infusion of propranolol and epinephrine was not significantly different from the control studies in any time period during the $2 \mathrm{hr}$ of the insulin clamp. Previous in vitro studies employing rat liver $(6,11)$ have suggested that epinephrine can stimulate hepatic glucose production via both $\alpha$ - and $\beta$-adrenergic receptors. However, the complete blockade of epinephrine-stimulated hepatic glucose production by propranolol in the present study indicates that the hepatic response to epinephrine in man is primarily mediated via the $\beta$-receptor. The difference between the rat and human studies may represent species variation.

Propranolol also completely reversed the effect of epinephrine on insulin-mediated peripheral glucose metabolism. Thus, the rate of glucose metabolism by the entire body during the hour of study increased from 3.34 to $6.78 \mathrm{mg} / \mathrm{kg} \cdot \mathrm{min}$, a value almost identical to the control study. This observation is consistent with in vitro studies demonstrating that propranolol reverses the epinephrine-mediated inhibition of glucose metabolism by muscle $(12,14)$. Because an $\alpha$-adrenergic blocking agent was not administered with epinephrine in the present study, the possibility that part of the insulin antagonistic effects is mediated via the $\alpha$ adrenergic receptor cannot be excluded.

In the present study hyperinsulinemia was associated with a significant decline in all plasma amino acids except alanine. The greatest decline was observed for the branch chain amino acids: leucine, isoleucine, and valine. When epinephrine was administered in conjunction with insulin, the fall in all circulating 
amino acids except alanine was $\sim 15-20 \%$ greater than when observed with insulin alone. Again, $\beta$-blockade with propranolol completely reversed the amino acid lowering effect of epinephrine. These results are consistent with previous in vitro studies in rat epitrochlearis muscle, demonstrating that epinephrine, acting through a $\beta$-adrenergic receptor, is a potent inhibitor of amino acid release from muscle (25). Thus, the effect of epinephrine on both glucose and amino acid metabolism appears to be exerted through the $\beta$-adrenergic receptor.

As compared with epinephrine infusion alone, an interesting feature of the present investigation was the twofold greater rise in plasma epinephrine levels observed when propranolol was infused with epinephrine. This suggests that propranolol, in some way, interferes with the degradation of epinephrine or causes its displacement from receptor sites. The interpretation of the present results would not be altered by this observation, however, because propranolol completely reversed the effects of epinephrine on all metabolic parameters measured despite the much higher circulating epinephrine levels.

\section{ACKNOWLEDGMENTS}

We wish to thank Lois Misciewicz for her expert technical assistance and Dr. Rosa Hendler for performing the plasma epinephrine determinations.

This work was supported in part by grants from the Juvenile Diabetes Foundation (78R294), the National Institutes of Health (AM24092), and the American Diabetes Foundation.

\section{REFERENCES}

1. Sacca, L., R. Sherwin, and P. Felig. 1978. Effect of sequential infusions of glucagon and epinephrine on glucose turnover in the dog. Am. J. Physiol. 235(3): E287-E290.

2. Eigler, N., L. Sacca, and R. Sherwin. 1979. Synergistic interactions of physiological increments of glucagon, epinephrine, and cortisol in the dog. J. Clin. Invest. 63: 114-123.

3. Altszuler, N., R. Steele, I. Rathgeb, and R. C. DeBodo. 1967. Glucose metabolism and plasma insulin levels during epinephrine infusion in the dog. Am. J. Physiol. 212(3): 677-682.

4. Coore, H. G., and P. J. Randle. 1964. Regulation of insulin secretion studied with pieces of rabbit pancreas incubated in vitro. Biochem. J. 93: 66-78.

5. Porte, D. 1967. A receptor mechanism for the inhibition of insulin release by epinephrine in man. J. Clin. Invest. 46: $86-94$.

6. Exton, J. H., G. A. Robinson, E. W. Sutherland, and C. R. Park. 1971. Studies on the role of adenosine $3^{\prime}, 5^{\prime}-$ monophosphate in the hepatic actions of glucagon and catecholamines. J. Biol. Chem. 246: 6166-6177.

7. Tolbert, M. E., F. R. Butcher, and J. N. Fain. 1973. Lack of correlation between catecholamine effects on cyclic adenosine adenosine $3^{\prime}, 5^{\prime}$-monophosphate and gluconeogenesis in isolated rat liver cells. J. Biol. Chem. 248: 5686-5692.
8. Kneer, N. M., A. L. Bosch, M. G. Clark, and H. A. Lardy. 1974. Glucose inhibition of epinephrine stimulation of hepatic gluconeogenesis by blockade of the alpha receptor function. Proc. Natl. Acad. Sci. U. S. A. 71: 4523-4527.

9. Exton, J. H., and C. R. Park. 1966. The stimulation of gluconeogenesis from lactate by epinephrine, glucagon, and cyclic- $3^{\prime}, 5^{\prime}$-adenylate in the perfused rat liver. Pharmacol. Rev. 18:181-188.

10. Exton, J. H., and C. R. Park. 1968. Control of gluconeogenesis in liver. II. Effects of glucagon, catecholamines and adenosine- $3^{\prime}, 5^{\prime}$-monophosphate on gluconeogenesis in the perfused rat liver. J. Biol. Chem. 243: 4189-4196.

11. Sherline, P., A. Lynch, and W. H. Glinsmann. 1972. Cyclic AMP and adrenergic receptor control of rat liver glycogen metabolism. Endocrinology. 91: 680-690.

12. Abramson, E. A., and R. A. Arky. 1968. Role of beta adrenergic receptors in counterregulations to insulininduced hypoglycemia. Diabetes. 17: 141-146.

13. Walass, O., and E. Walass. 1950. Effects of epinephrine on rat diaphragm. J. Biol. Chem. 187: 769-776.

14. Sloan, I., P. Saul, and I. Bihler. 1978. Influence of adrenalin on sugar transport in soleus, a red skeletal muscle. Mol. Cell. Endocr. 10: 3-12.

15. Antonis, A., M. L. Clark, R. L. Hodge, and T. R. E. Pilkington. 1967. Receptor mechanisms in the hyperglycaemic response to adrenaline in man. Lancet. I: $1135-1137$.

16. Gerich, J. E., M. Lorenzi, E. Tsalakian, and J. H. Karam. 1967. Studies on the mechanism of epinephrine-induced hyperglycemia in man. Diabetes. 25: 65-71.

17. DeFronzo, R. A., J. Tobin, and R. Andres. 1979. The glucose clamp technique. A method for quantifying insulin secretion and resistance. Am. J. Physiol. 237(3): E214E223.

18. Sherwin, R. S., R. Hendler, R. A. DeFronzo, J. A. Wahren, and P. Felig. 1977. Glucose homeostasis during prolonged suppression of glucagon and insulin secretion by somatostatin. Proc. Natl. Acad. Sci. U. S. A. 74: 348-352.

19. Wise, J. K., R. Hendler, and P. Felig. 1973. Influence of glucocorticoids on glucagon secretion and plasma amino acid concentrations in man. J. Clin. Invest. 52: 2774-2782.

20. Cryer, P. E. 1976. Isotope-derivative measurement of plasma norepinephrine and epinephrine in man. Diabetes. 25: 1071-1085.

21. Halter, J. B., A. E. Pflug, and D. Porte. 1977. Mechanism of plasma catecholamine release during surgical stress in man. J. Clin. Endocrinol. Metab. 45: 936-944.

22. Christensen, N. J. 1974. Plasma norepinephrine and epinephrine in untreated diabetics, during fasting and after insulin administration. Diabetes. 23: 1-8.

23. Soman, V. R., H. Shamoon, and R. Sherwin. 1980. Effects of physiologic infusion of epinephrine in normal humans: relationship between the metabolic response and $\beta$-adrenergic binding. J. Clin. Endocrinol. Metab. In press.

24. DeFronzo, R. A., E. Ferrannini, R. Hendler, J. Wahren, and P. Felig. 1978. Influence of hyperinsulinemia, hyperglycemia, and the route of glucose administration on splanchnic glucose exchange. Proc. Natl. Acad. Sci. U. S. A. 75: 5173-5177.

25. Garber, A. J., I. E. Karl, and D. M. Kipnis. 1976. Alanine and glutamine synthesis and release from skeletal muscle. IV. $\beta$-Adrenergic inhibition of amino acid release. $J$. Biol. Chem. 251: 852-857. 